\title{
ANALYSIS OF ECONOMIC ASPECTS OF BUCKWHEAT, PANICUM AND RICE GROWING AND PRODUCTION IN CENTRAL AND EASTERN EUROPE AND UKRAINE
}

\author{
Oleksander Averchev' ${ }^{1}$, Hanna Fesenko²
}

\begin{abstract}
The purpose of the article is to study the analysis of economic aspects of buckwheat, Panicum and rice growing and production in Central and Eastern Europe and Ukraine $(2016,2017,2018)$. The subject of the study is the market of large crops in Central and Eastern Europe and Ukraine. The study is based on the analysis of statistics of production of buckwheat, rice and Panicum for 2016-2018. It was established that in the current and the previous grain seasons buckwheat was in the list of objects of state regulation that set minimum and maximum intervention prices, which gave grounds to the Agrarian Fund of Ukraine to carry out financial or commodity interventions in case of unfavorable price situation on the market. It is proved that Ukraine has everything that is needed for developing its own rice industry. The favorable natural and climatic conditions of southern Ukraine, the availability of engineered rice irrigation systems, the close cooperation and friendship of the Rice Institute with commodity producer, varieties of domestic breeding, environmentally safe cultivation technology make it possible to obtain high yields. So meteorological and hydrological conditions therefore play an important role in levels of crop production but they also have a knock-on effect on prices through the causal effect of supply and demand. This is true for the EU, as it is across the globe. Of course, with the European Union covering such a large area and including such diverse climates, adverse weather conditions in one region are often offset by optimum conditions in another. However, where the production of certain crops is concentrated in a few regions, the EU production levels will be particularly susceptible to weather conditions as well as to pest attacks. Where known adverse weather conditions have impacted on crop levels this is mentioned. Cereal harvest in the EU higher in 2017 despite drought conditions in many areas of Central and Southern Europe and reduction in cultivated area. Monsoon countries, which due to weather conditions harvest twice a year, do not have much higher and sometimes even lower rice yields than Ukraine does. It is set that despite the difficult weather conditions, the grain industry provides sustainable production, which guarantees the food and economic security of the country. Cereal crops are the basis for the formation and maintenance of the state's strategic food, feed and export balance.
\end{abstract}

Key words: production, cereal crops, growing, buckwheat, rice, Panicum.

JEL Classification: O13, Q11, Q14, Q18

\section{Introduction}

The current stage of development of the agrarian sector of the Ukrainian economy is characterized by complex dynamic transformations, which is connected with the constant changes of supply and demand of agricultural products in the market, the cost of production means and global climate changes, which were reflected on the Ukraine territory.

In Ukraine, grain production has been and will be a leading sector of agriculture. Increasing grain production is a strategically and environmentally important task that underpins the country's food independence. The grain economy of the country forms a food fund, provides livestock with feed grain, creates state grain reserves and forms a certain share of exports. Along with the main cereal crops such as wheat, corn, barley, an important role is played by cereal crops, dominated by buckwheat, Panicum and rice.

The natural climatic conditions and fertile lands of Ukraine contribute to the development of the cereal industry and make it possible to obtain high-quality grain cereals in volumes sufficient to meet domestic needs and to form export potential. At the same time, further development of the industry requires a thorough

Corresponding author:

${ }^{1}$ State Higher Educational Institution “Kherson State Agrarian University”, Ukraine.

E-mail: averchev2011@ukr.net

ORCID: https://orcid.org/0000-0002-8333-2419

2 State Higher Educational Institution “Kherson State Agrarian University”, Ukraine.

E-mail: annaavercheva@ukr.net 
economic assessment, revision of a number of positions regarding the technical, technological, organizational, economical and market conditions of functioning of the whole complex.

Ukraine's cereals sector is strategic for the national economy. Cereal grain and its products have always been liquid because they form the basis of the state's food base and security. Cereals are of great importance in the human diet. In the agricultural market, cereal crops have leading positions in export, processing and inland consumption, which proves their strategic role in ensuring the food and economic security of the country and that is why for farmers it is an important task to maintain and increase the volume of grain production. Buckwheat, Panicum and rice are one of the promising high-yielding cereal crops.

\section{Analysis of economic aspects of cultivation and production of cereals in Central and Eastern Europe}

Crops can be broadly categorized into two groups, those that are non-perennial and those that are perennial. Non-perennial crops are those that do not last more than two growing seasons and typically only one. Perennial crops last for more than two growing seasons, either dying back after each season or growing continuously; these are also termed permanent crops.

Crop production is particularly sensitive to prevailing weather conditions at key times of the year. For example, depending on a crop's stage of development, heavy spring frosts can damage the growth of cereals and destroy fruit blossoms. Likewise, summer droughts can cause crops to wither or to scorch and strong winds and heavy rain can flatten crops, making them hard to harvest.

Meteorological and hydrological conditions therefore play an important role in levels of crop production but they also have a knock-on effect on prices through the causal effect of supply and demand. This is true for the EU, as it is across the globe. Of course, with the European Union covering such a large area and including such diverse climates, adverse weather conditions in one region are often offset by optimum conditions in another. However, where the production of certain crops is concentrated in a few regions, the EU production levels will be particularly susceptible to weather conditions as well as to pest attacks. Where known adverse weather conditions have impacted on crop levels this is mentioned.

Cereal harvest in the EU is higher in 2017 despite drought conditions in many areas of Central and Southern Europe and reduction in cultivated area.

The harvested production of cereals (including rice) in the EU was 309.9 million tonnes in 2017 (see Figure 1), about $11.9 \%$ of global production. This represented a rebound of $+2.7 \%$ or 8.2 million tonnes more than in 2016, despite drought conditions in many areas of Central and Southern Europe and a reduction in cultivated areas of 1.6 million hectares. To put this in some context, the EU's harvested production of cereals in 2017 remained some 23 million tonnes lower than the record harvest of 332.6 million tonnes recorded in 2014.

France harvested 68.5 million tonnes of cereals in 2017, a little more than one fifth (22.0\%) of the EU's total production. Germany harvested 45.6 million tonnes (14.7\% of the EU total) and Poland harvested 31.9 million tonnes (10.3\%).

The overall increase in harvested production at the level of the EU was driven by the strong rebound $(+26.4 \%)$ in France, as well as in Poland (+7.0\%) but also Romania (+24.7\%). The higher production levels in France and Romania resulted from much higher yields, as the cultivated areas in both were lower in 2017 than in 2016 ( $-2.1 \%$ and $-5.4 \%$ respectively). Higher production levels in some Member States offset, at the EU level, the lower harvested production levels in drought-hit Spain (-30.9\% on 2016, with cultivated areas only $-3.6 \%$ lower), Hungary (15.8\%, with cultivated areas $-6.4 \%$ lower in 2017$)$, Italy $(-11.1 \%$, with cultivated areas down $-3.3 \%)$ and smaller cerealproducing countries like Slovakia (-28.1\%), Croatia (-23.8\%), Greece (20.9\%), Austria (14.5\%), Slovenia (14.3\%) and Czechia (-13.3\%).

Cereal harvest higher mainly due to sharp rise in wheat production but also grain maize.

The EU harvested 142.6 million tonnes of common wheat and spelt in 2017, representing $46.0 \%$ of all cereal grains harvested. This was 7.9 million tonnes more than in 2016, an increase of $+5.9 \%$, despite cultivated areas being $-3.6 \%$ lower. The harvested production of grain maize and corn-cob-mix (CCM) in the EU was 64.7 million tonnes in 2017, up 1.9 million tonnes (or $+3.0 \%$ ) on 2016 , despite the cultivated area also being $-3.4 \%$ lower.

The harvested production of oats and spring cereal mixtures was 11.3 million tonnes across the EU in 2017, an increase of $+4.0 \%$, reflecting a similar rate of increase in cultivated area. Most of this rise was due to higher yields for spring cereal mixtures, as the harvested production of oats remained broadly unchanged $(+0.4 \%)$ despite an increase of $+2.5 \%$ in the cultivated area.

To complete the picture, the harvested production of barley in 2017 was $-2.3 \%$ lower than in 2016 at 58.7 million tonnes.

With the average apparent barley yield across the EU being similar in 2017 to that in 2016, the lower harvested production reflected the reduced cultivated area. The production of rye and winter cereal mixtures $(-0.4 \%)$ remained similar to the level in 2016.

Picardie and Centre-Val de Loire are the most important regions for wheat production, Bavaria for barley.

At a more detailed level, the EU regions with the largest production of wheat in 2017 were the two French 


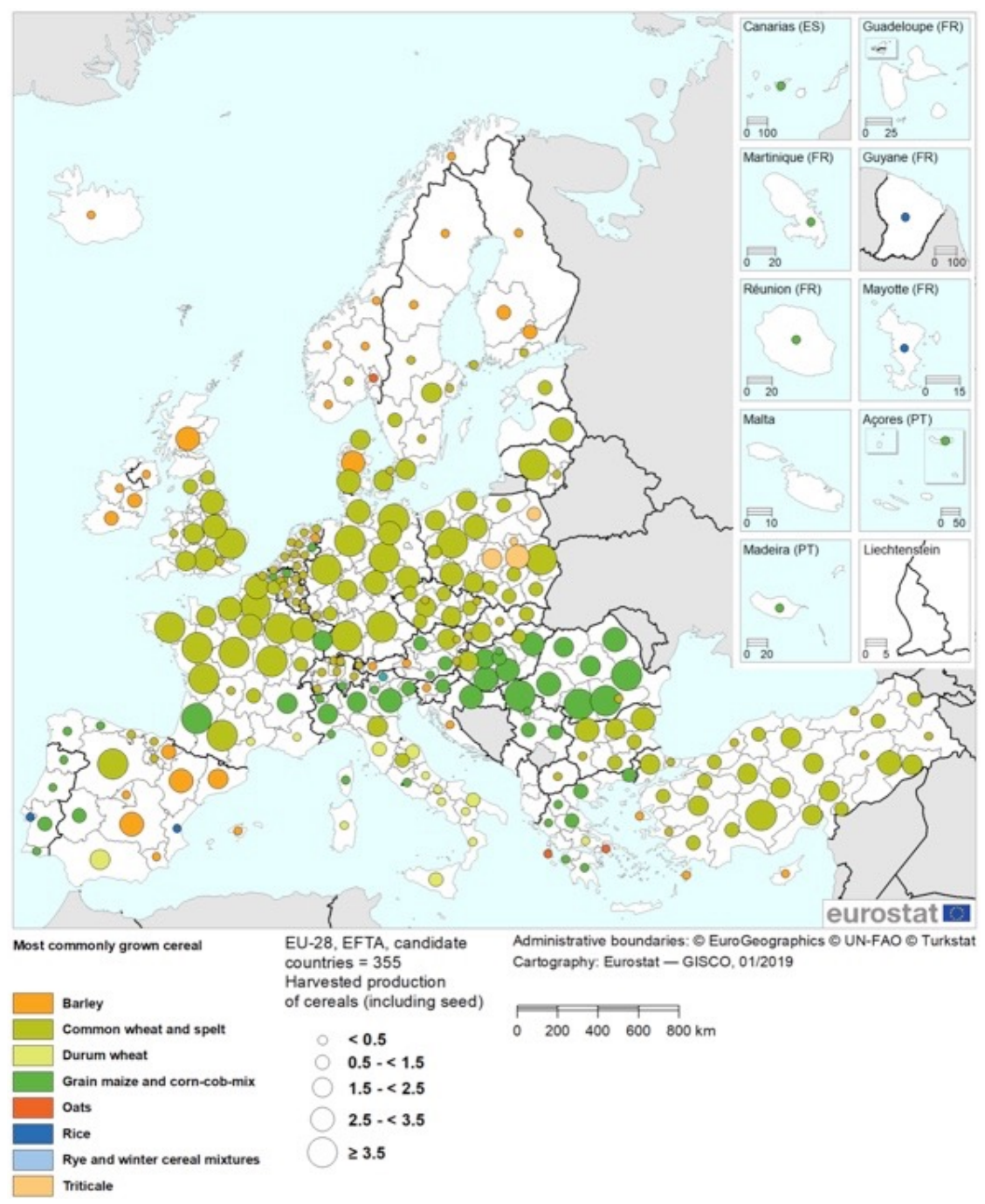

Figure 1. Harvested production of cereals (including seed)

and most commonly grown cereals, by NUTS 2 regions, 2015-2017, (million tonnes)

regions of Centre-Val de Loire (3.3\% of the EU total) and Picardie (3.2\%). Other regions with considerable wheat production were the German regions of Bayern $(2.7 \%)$ and Niedersachsen $(2.4 \%)$, as well as the Lithuanian region Vidurio ir vakaru Lietuvos regionas (Central and West Lithuania) (2.6 \%). The German region of Bayern (Bavaria), renowned for its beer production, was the EU region with the highest barley production in 2017 (3.9\% or the EU total). Other important regions for barley production were CentreVal de Loire (3.4\%) and Champagne-Ardenne (3.1\%) in France and Castilla-la Mancha (3.2\%) in Spain.

Prices for wheat, barley and rye bounced higher in 2017 but were still about 30\% (see Figure 2) lower than the recent 2012 peak.

The average price of cereals in 2017 bucked the downward trend of the previous four years, rising by $+3.0 \%$ in real terms. There were price rises for wheat (an average $+4.5 \%$ in real terms), barley $(+5.6 \%)$ and rye $(+6.4 \%)$.
In contrast there were further declines, albeit moderate, for grain maize $(-1.7 \%)$ and oats $(-0.5 \%)$. However, for all types of cereal, real terms prices remained about $30 \%$ lower than the recent peak price levels of 2012. The downward pressure on cereal prices resulted from a series of successive global record harvests.

\section{Economic aspects of buckwheat, rice and Panicum growing and production in Ukraine}

Agriculture has long become a business. In addition, the main task for farmers is to maximize profits by increasing revenues and reducing costs. Therefore, each crop is viewed through an economic prism, that is, how much money can be obtained from its growing in the end per 1 ha. Buckwheat, Panicum and rice are among the promising high-yielding cereals (Averchev, 2015).

Much attention is paid to buckwheat production by farms that have standing orders from cereals producers, since buckwheat does not belong to leading crops. Most 


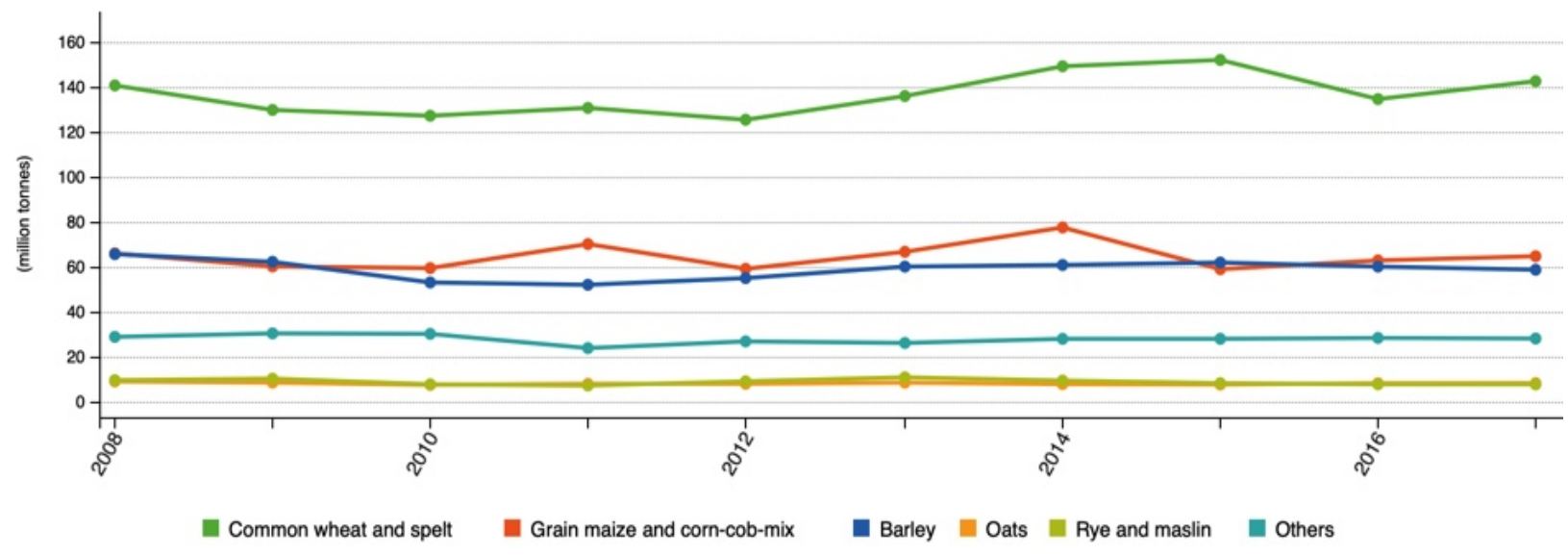

Rye and maslin includes mixture of rye with other winter sown cereals. Others includes rice, triticale and sorghum. Grain maize and corn-cob-mix includes estimates for Denmark 2008-2009 and Sweden 2008. Rye and maslin includes estimate for Italy 2013.

Figure 2. Deflated price indices for cereals, the EU-28, 2010-2017 $(2010=100)$

farms grow buckwheat to support their own beekeeping, and grain is more commonly sold and processed in the region where it is produced. It is also used in fodder production, namely small grain, as well as bran, which are obtained during grain processing. This crop is considered a valuable honey plant and a good forecrop in crop rotation.

Previously, buckwheat was considered a strategically important food product that had an impact on food security in the country. In recent years, many alternative types of cereals which can replace buckwheat have appeared in the domestic market of Ukraine, which is why this type of product affects the overall food situation in the country. Price controls the level of consumption. So now we have the following price situation: buckwheat costs 10\% more than rice (Orlenko, 2016).

Consumer basket in Ukraine is calculated in such a way that buckwheat consumption per year is $2 \mathrm{~kg} /$ person, rice $-2.5 \mathrm{~kg} /$ person, and Panicum - $1 \mathrm{~kg} /$ person. At the same time, compared to the countries of Europe (Poland), the consumption of buckwheat is $75 \%$ lower than in Ukraine and for rice this number is 65\%.

Among all the cereal crops, rice is the most important, most productive, most ancient and most caloric crop. It is grown on all continents of the world. The largest areas are dedicated to rice, the same as to wheat and maize. The area of rice sowing has tripled in the last 100 years and now amounts more than 150 million hectares. Rice has a higher potential yield compared to wheat at $800-1000 \mathrm{~kg} / \mathrm{ha}$, which provides an annual gross harvest of almost 600 million tons. Rice has about 30 species, but in cultivation the most common is Oryza Sativa, an annual plant with a height of $50-200 \mathrm{~cm}$, $80-140 \mathrm{~cm}$ in Ukraine.

Not only in Ukraine, but in most rice sowing countries of the world, the rice systems are located near the sea coasts and are in close proximity to the resort areas. In the early years, the technology of rice growing did not meet the requirements of ensuring ecological balance. Therefore, the scientists of the Institute of Rice of the National Academy of Agrarian Sciences of Ukraine conducted extensive research and created a new environmentally friendly technology, taking into account all the requirements of environmental protection, which received positive conclusions of state expertise. The experience of the Rice Institute on the environmental problem solving has attracted the attention of foreign colleagues.

The main task of modern agricultural production, including rice, is to obtain a high economically viable grain yield, which is largely facilitated by the cultivar. Rice growing as an intensive industry requires new varieties with high productivity, adapted to biotic and abiotic environmental factors, which in different agroecological conditions could give maximum return on investment (Scorohod, 2011).

Nowadays, such valuable cereal crop as Panicum receive insufficient attention, although it is characterized by high drought tolerance, which is quite positive feature especially taking into account the gradual changes in climate over the last decade. And this crop also provides fairly stable yields in our area, regardless of weather conditions, for example, unlike buckwheat (www.fao.org).

Panicum is one of the major cereal crops in the world. This spring cereal is appreciated for its high taste in grain (millet). It is resistant to drought. It is a culture of short daylight that has a fast growing season. Due to these properties, it is often sown as a postharvest crop.

However, Panicum has never held a leading role among crops in the agricultural sector of Ukraine. It is one of the major cereal crops of Ukraine, the value of which is determined by the virtually waste-free use of processing products in the food, feed, pharmaceutical, microbiological, industrial branches, as well as the possibility of its growing in post-harvested sowings, which ensures two yields and increase the yield per 
hectare. Unprocessed Panicum is used as a very valuable animal feed. The waste that is received during the processing of grain into cereals (flour, husk) is also a feed. Panicum straw and hay are close to meadow hay by their qualities. Panicum is widely used as a replacement crop in the event of re-sowing of fallen winter and early spring crops, which is especially important for yield and income of the current year. In the composition of Panicum protein content is $12 \%$, starch is $81 \%$, fat is $3.5 \%$, fiber is $1-2 \%$. The grain is rich with minerals, trace elements, vitamins B1, B2, B5, B6, C, carotenoids and other physiologically active elements. Also, the culture contains a large amount of starch, so it is used for the production of alcohol (The Main Journal of Agribusiness, 2018).

The underestimation of the value of Panicum growing is wrong. Panicum is a high-yielding cereal crops. By adhering to the growing technology, it yields grains over $5000 \mathrm{~kg} / \mathrm{ha}$. These yields are often higher than yields of other cereals.

In 2018, buckwheat provided the largest acreage, production and yield, and rice provided the least (Table 1).

Table 1

Production of buckwheat, Panicum and rice in Ukraine for 2015-2018

\begin{tabular}{|l|c|c|c|}
\hline \multicolumn{1}{|c|}{ Crop } & $\begin{array}{c}\text { Harvested } \\
\text { area, } \\
\text { thousands } \\
\text { of hectare }\end{array}$ & $\begin{array}{c}\text { Gross } \\
\text { mass after } \\
\text { processing, } \\
\text { thousand tons }\end{array}$ & $\begin{array}{c}\text { Yield, } \\
\mathrm{kg} / \mathrm{ha}\end{array}$ \\
\hline \multicolumn{3}{|c|}{2015} \\
\hline Buckwheat & 127.7 & 128.1 & 1000 \\
\hline Panicum & 112.8 & 213.2 & 1890 \\
\hline Rice & 11.7 & 62.5 & 5340 \\
\hline \multicolumn{5}{|c|}{2016} \\
\hline Buckwheat & 153.7 & 176.4 & 1150 \\
\hline Panicum & 107.7 & 189.7 & 1760 \\
\hline Rice & 12.0 & 64.7 & 5390 \\
\hline \multicolumn{5}{|c|}{2017} \\
\hline Buckwheat & 185.3 & 180.4 & 970 \\
\hline Panicum & 56.1 & 84.4 & 1500 \\
\hline Rice & 12.7 & 63.9 & 5050 \\
\hline \multicolumn{5}{|c|}{113.3} & 137.0 & 1260 \\
\hline Buckwheat & 54.8 & 80.5 & 1460 \\
\hline Panicum & 12.6 & 69.2 & 5490 \\
\hline Rice & \multicolumn{3}{|c|}{} \\
\hline
\end{tabular}

According to official statistics, the area from which buckwheat was harvested in Ukraine in 2018 decreased by 72 thousand hectares, to 113.3 thousand hectares. At the same time, the average yield increased by $290 \mathrm{~kg} / \mathrm{ha}$ and amounted $1260 \mathrm{~kg} / \mathrm{ha}$, the gross yield exceeded 13700 thousand tons, which is $7.0 \%$ more than in 2015 .

The situation is better with rice. The area from which the yield were harvested in 2018 amounted 12.6 thousand hectares, which is more than 0.6 thousand hectares in 2016 and by 0.9 thousand hectares more compared to 2015. At the same time, the yield increased by $490 \mathrm{~kg}$ / ha compared to 2017 and it is $5490 \mathrm{~kg}$ / ha at a gross yield of 69.2 thousand tons.

Rice, along with buckwheat, is the leader of consumption among cereals among the population of Ukraine. Total domestic rice production provides only $35 \%$ of the market's needs, so this market is now import-dependent. Although by 2014, the situation was somewhat different: rice plantations located in Crimea made it possible to grow much of the country's needs.

In 2018, Ukrainian agrarians harvested 805 thousand tonnes of Panicum, which is $4.6 \%$ less than in the previous year. In particular, agricultural enterprises produced 52.0 thousand tons of Panicum, which is $5.9 \%$ more than in 2017, and households produced 28.5 thousand tons $(-20.2 \%)$.

The decrease in the volume of Panicum production is due to both the reduction of acreage under it and the decrease in the average crop yield. Last year, 54.8 thousand hectares were sown with Panicum, which is $2.3 \%$ less than in 2017 . The average yield decreased by $2.7 \%$ and amounted to $1460 \mathrm{~kg} / \mathrm{ha}$.

According to the estimates of grain market experts, it is planned to reduce the area under buckwheat in Ukraine, because buckwheat growing technology provides certain specific features. It is necessary to take into account the norms of buckwheat sowing, biology of nutrition, growth, and flowering for high yields of buckwheat. That is why it was given the status of a capricious crop.

In total, there are currently 30,000 ha of rice irrigation systems in Ukraine. In recent years, rice has been sown on an area of about 13 thousand hectares, and with the restoration of such systems, especially in the Odessa region, it is possible to increase the area under rice by another 2 thousand hectares. The general climatic conditions and water resources of Ukraine allow growing rice on the area of more than 100 thousand hectares.

Experts say that at this stage it is necessary to increase the area of rice crops. The crop itself is not easy to grow, it requires a special climate: heat and humidity. In Ukraine, farmers buy seeds at the only rice institute in Ukraine, where more than 800 hectares of this type of cereals are grown (Informational digest, 2018).

Rice cereals of domestic production are made exclusively from grown grain, since there are no state stocks of rice in Ukraine. It contains the required range of valuable indicators of quality, which is not inferior to the imported rice, and far exceeds it by other qualities, including culinary ones. However, under market conditions, its price is forced to equate to low-calorie. The cheapest third-grade cereal made from the grain of state stocks of exporting countries after long-term storage or of its mixture with freshly produced grain comes in large quantities to Ukraine from abroad. Such grain quality is much worse than domestic quality, both in terms of biochemical parameters and the way it looks 
Table 2

Structure of buckwheat production in Ukraine for 2015-2018

\begin{tabular}{|c|c|c|c|c|c|c|c|c|c|c|c|c|}
\hline \multirow{2}{*}{$\begin{array}{l}\text { Regions } \\
\text { of Ukraine }\end{array}$} & \multicolumn{4}{|c|}{$\begin{array}{l}\text { Harvested area, } \\
\text { thousands of hectare }\end{array}$} & \multicolumn{4}{|c|}{$\begin{array}{c}\text { Gross mass after processing, } \\
\text { thousand tons }\end{array}$} & \multicolumn{4}{|c|}{$\begin{array}{l}\text { Yield, } \\
\mathrm{kg} / \mathrm{ha}\end{array}$} \\
\hline & 2015 & 2016 & 2017 & 2018 & 2015 & 2016 & 2017 & 2018 & 2015 & 2016 & 2017 & 2018 \\
\hline Ukraine & 127.7 & 153.7 & 185.3 & 113.3 & 128.1 & 176.4 & 136.8 & 137.0 & 1000 & 1150 & 970 & 1210 \\
\hline Vinnytsia & 1.0 & 9.9 & 11.8 & 7.7 & 1.4 & 13.9 & 13.6 & 10.1 & 15.1 & 14.0 & 11.5 & 13.0 \\
\hline Zhytomyr & 6.3 & 10.1 & 20.1 & 21.3 & 4.4 & 13.4 & 16.1 & 28.0 & 7.0 & 13.2 & 10.2 & 13.1 \\
\hline Transcarpathian & 0.2 & 0.1 & 0.4 & 0.3 & 0.1 & 0.1 & 0.5 & 0.6 & 5.3 & 9.6 & 15.9 & 19.2 \\
\hline Kyiv & 7.7 & 9.4 & 13.0 & 6.9 & 9.5 & 14.9 & 12.0 & 10.7 & 12.5 & 15.7 & 10.7 & 15.6 \\
\hline Sumy & 17.7 & 21.0 & 21.5 & 11.1 & 23.8 & 23.4 & 20.3 & 11.6 & 13.4 & 11.1 & 11.5 & 10.4 \\
\hline Kharkiv & 12.5 & 19.2 & 19.8 & 9.0 & 30.6 & 20.6 & 13.7 & 10.4 & 24.5 & 10.8 & 6.9 & 11.6 \\
\hline Kherson & 1.0 & 1.5 & 1.6 & 0.4 & 0.9 & 1.7 & 1.5 & 0.5 & 9.1 & 10.8 & 9.2 & 9.8 \\
\hline Khmelnytskyi & 10.7 & 12.0 & 16.9 & 11.9 & 10.0 & 16.4 & 14.1 & 18.6 & 9.4 & 13.6 & 13.0 & 15.6 \\
\hline
\end{tabular}

and smells, but due to the cheap and low purchasing ability of the population, it dictates a general decrease in prices in the market (Scorohod, 2011).

\section{Analysis of buckwheat market}

In Ukraine, the most favorable zones for buckwheat growing are the forest-steppe and Polissia zones, where natural and climatic conditions allow protecting crops from arid winds, which allows plants to grow better during the growing season and have higher yields. Soils and conditions of other regions are also suitable for buckwheat growing, but due to low yields, the acreage of this crop is insignificant. According to the results of 2018, the largest gross buckwheat harvests were received in Zhytomyr (28.0 thousand tons), Khmelnytskyi (18.6 thousand tons), Sumy (11.6 thousand tons), Kyiv (10.7 thousand tons). t), Kharkiv (10.4 thousand tons) and Vinnytsia (10.1 thousand tons) regions. For comparison, the yield of this crop in the Kherson region is $980 \mathrm{~kg}$ / ha with a gross harvest of 0.5 thousand tons (Table 2).

\section{Analysis of Panicum market}

Analysis of the Panicum market, according to a study of the Association of Ukrainian Club of Agrarian Business, showed that it is one of the most promising niche agrarian markets. Despite the small volumes of
Panicum yield in Ukraine (about 150-200 thousand tons annually), the country occupies a leading position in the world export of these products.

Growing Panicum is beneficial in areas where other cereals suffer from drought. Panicum is heat resistant, forms a high yield even at high temperatures. This cereal is a replacement crop and, even in the most unfavorable years, provides a yield of $1000 \mathrm{~kg} / \mathrm{ha}$. Subject to the requirements of agricultural technology and optimal sowing density, the yield will be $1500-1700 \mathrm{~kg} / \mathrm{ha}$.

In Ukraine, the largest volumes of Panicum production in 2018 were in the Kharkiv (13390 thousand kilos) and Dnipropetrovsk (9330 thousand kilos) regions. The highest yields were in the Cherkasy $(2940 \mathrm{~kg} / \mathrm{ha})$, Khmelnytskyi (2890 kg / ha), Poltava (2310 kg / ha), Kyiv (2220 kg / ha), Kharkiv (2180 kg / ha) areas. In the Kherson region, the gross harvest amounted to 7340 thousand kilos with a yield of $1170 \mathrm{~kg} / \mathrm{ha}$.

Panicum growing will be most effective after legumes, perennial grasses, clear of weeds of winter and arable crops. It is not recommended to sow Panicum after corn (as well as before it), as both plants are affected by the pediculate.

\section{Analysis of rice market}

Rice in Ukraine is grown in the Kherson and Odessa regions. Also today there is an interest in the cultivation

Table 3

Structure of Panicum production in Ukraine for 2016-2018

\begin{tabular}{|c|c|c|c|c|c|c|c|c|c|}
\hline \multirow{2}{*}{$\begin{array}{l}\text { Regions } \\
\text { of Ukraine }\end{array}$} & \multicolumn{3}{|c|}{$\begin{array}{l}\text { Harvested area, } \\
\text { thousands of hectare }\end{array}$} & \multicolumn{3}{|c|}{$\begin{array}{c}\text { Gross mass after processing, } \\
\text { thousand tons }\end{array}$} & \multicolumn{3}{|c|}{$\begin{array}{l}\text { Yield, } \\
\mathrm{kg} / \mathrm{ha}\end{array}$} \\
\hline & 2016 & 2017 & 2018 & 2016 & 2017 & 2018 & 2016 & 2017 & 2018 \\
\hline Ukraine & 107.7 & 56.1 & 54.8 & 1896.7 & 844.0 & 804.6 & 1760 & 1500 & 1460 \\
\hline Dnipropetrovsk & 12.3 & 6.2 & 5.9 & 21.43 & 8.26 & 9.33 & 1740 & 1330 & 1570 \\
\hline Zaporizhzhia & 17.7 & 6.3 & 6.0 & 27.33 & 8.88 & 4.33 & 1540 & 1400 & 720 \\
\hline Kyiv & 1.5 & 0.5 & 1.2 & 2.48 & 0.82 & 2.66 & 1640 & 1640 & 2220 \\
\hline Poltava & 4.2 & 2.2 & 2.4 & 9.08 & 3.85 & 5.55 & 2170 & 1770 & 2310 \\
\hline Kharkiv & 11.9 & 5.1 & 6.1 & 22.32 & 8.90 & 13.39 & 1860 & 1750 & 2180 \\
\hline Kherson & 12.3 & 6.8 & 6.3 & 22.72 & 12.11 & 7.34 & 1850 & 1780 & 1170 \\
\hline Khmelnytskyi & 0.1 & 0.4 & 0.1 & 0.45 & 0.67 & 0.35 & 2650 & 1740 & 2890 \\
\hline Cherkasy & 1.6 & 0.4 & 0.6 & 3.22 & 0.79 & 1.6 & 2010 & 2310 & 2940 \\
\hline
\end{tabular}


of this crop in the Poltava and Dnipropetrovsk regions. Climate change in the country has no impact on the rice market. Everything is determined by technology. Rice can only be grown on special engineering-grade irrigation systems, most of which have been constructed some time ago. On a normal field, it is very difficult to grow this crop, except in the presence of drip irrigation, but the cost of such equipment is quite expensive.

Prior to the annexation of Crimea, the main crops were rice on the peninsula. Ukraine exported the goods to Turkey, Romania and Bulgaria. For domestic consumption it is needed more than 150 thousand tons, and in Ukraine only 70 thousand tons is harvested. In general, Ukraine meets its own needs in this crop by $35 \%$ by purchasing parts of it in Pakistan, China, India and Vietnam.

There are currently three directions for increasing the area under rice in Ukraine:

- restoration of existing rice systems. This can increase the acreage by 2 thousand hectares, i.e. up to 15 thousand hectares;

- the use of contour and drip irrigation, which help to equip larger areas, but today drip tape is the main component that increases the cost of production that is 11-15 thousand UAH / ha annually;

- spreading the positive experience of 2018 regarding the involvement of fish farmers in rice cultivation, since they already have ponds, pure water which can be used for irrigation, that can increase the area under rice by another 5-6 thousand hectares.

In 2018, the gross rice harvest in the Kherson region was 44.5 thousand tons, and the yield was $5770 \mathrm{~kg} / \mathrm{ha}$ with the harvested area of 7.7 thousand ha. In the Odessa region, the gross harvest was 24.7 thousand tons, and the yield was $5050 \mathrm{~kg} /$ ha with the harvested area of 4.9 thousand ha.

In the South of Ukraine, rice is sown mainly along the Black Sea, that is, the coastal resort area, in connection with which scientifically grounded systems of agriculture and water use are of particular relevance, which should maintain a safe phytosanitary condition, promote the reproduction of humus in the soil and stabilize ecological situation in rice sowing areas.

Washing regime during rice growing promotes soil salinization, which makes it possible to grow other crops in rice crop rotation. Thus, rice sowing not only provides the country with valuable food, but also improves soil fertility. Scientific research and practice show that if rice ceases to grow in a few years, there will be secondary salinization of the soil, which will again turn these lands into a desert (The Main Journal of Agribusiness, 2018).

\section{Study of consumption of buckwheat, rice and Panicum}

Buckwheat consumption in the domestic market tends to decline. The main reasons for this are high purchase prices for buckwheat grain, as well as declining population. While in 2015, buckwheat grain food consumption was 120 thousand tonnes, in 2017 it decreased to 108 thousand tonnes. At the same level, buckwheat food consumption remained last year. Thus, buckwheat production was sufficient to meet domestic nutritional requirements.

In 2016, after a sharp decline in buckwheat production, there was a gradual rise in prices for grain. In the period to June 2016, buckwheat grain went up from 11 to 20 thousand UAH / $\mathrm{t}$ and buckwheat increased from 19 to 32 thousand UAH / t. Buckwheat production amounted to 176.4 thousand tonnes in 2016, which is $13.7 \%$ more than the previous year.

In the 2016-2018 marketing year the price situation was more stable. The minimum purchase prices for buckwheat grain and, consequently, for buckwheat groats were observed during the harvesting period, that is, at the beginning of the season, and their maximum growth was at the beginning of March. Thus, the purchase prices for buckwheat grain in the current season ranged from 13.5 to 18 thousand UAH / $t$, and for buckwheat groats from 23 to 27.5 thousand UAH / $t$.

In the 2017 season, Panicum prices rose situationally, which was primarily driven by an increase in demand and the quality characteristics of raw materials offered by farmers. Thus, after the seasonal decline in prices at the beginning of 2016-2017, demand prices in August 2016 were fixed in the range of 3000-3800 UAH / t. As demand increased and the number of grain products with high quality indicators decreased, prices began to rise, with their peak rising in March 2017. At the thought of the operator's market, the main reason of this situation was the activation of demand. However, the low quality characteristics of the raw materials offered on the market and the high prices often did not satisfy the buyers, who already began to lower demand prices at the end of March. So, in 2018 purchase prices for Panicum were fixed at the level of 8000-9000 UAH / t, but in October 2019 there was a decrease to $7200 \mathrm{UAH} / \mathrm{t}$ (Figure 1).

Table 4

Purchase prices for Panicum and buckwheat in Ukraine at the beginning of October 2019, UAH / t

\begin{tabular}{|c|c|c|}
\hline $\begin{array}{c}\text { Purchase prices } \\
\text { October 2019 }\end{array}$ & Buckwheat, UAH / & Panicum, UAH / t \\
\hline & 13000 & 7200 \\
\hline
\end{tabular}

Rice is a crop that consumes more moisture than others to develop. Therefore, the cost of its growing increases by about $30 \%$ each year due to the rise in price of water supply. This especially concerns not for selfflowing systems, but for systems using electric pumps, when the cost of water supply is also affected by the price of electricity. According to its biological needs, rice uses 13.5 thousand cubic meters per ha, taking into account evaporation, but in Ukraine on average it 
consumes more than 22-23 thousand cubic meters per ha (Scorohod, 2011).

The wholesale price of rice reduced from $18 \mathrm{UAH} / \mathrm{kg}$ at the beginning of the year to $14.5 \mathrm{UAH} / \mathrm{kg}$ now. There are two reasons for this. The first is that today we are saturating the market with our own products by $30-35 \%$, although by 2014 this indicator was at the level of $50 \%$. Therefore, Ukraine was less dependent on the global market environment. Today the world price of rice is reducing. The second reason identifies that rice and buckwheat belong to the category of more expensive cereals, and when the purchasing ability of the population decreases, one of the indicators of this phenomenon is the decline in demand for these products.

About 30 enterprises are engaged in rice production in Ukraine. Domestic production is up to 70 thousand tons of raw material. The harvest is partly spent on seeds and the rest is processed.

\section{Conclusions}

The domestic market is experiencing a decline in demand for buckwheat and rice grain in the current year. This is due to the overall rise in prices in this market segment. Consumers prefer cheaper types of cereals. However, in the new season, the situation on the buckwheat market may change.

In the current and previous grain seasons, buckwheat was on the list of objects of state regulation, which set minimum and maximum intervention prices that gave reason to the Agrarian Fund of Ukraine to carry out financial or commodity interventions in case of unfavorable price situation on the market. However, the types of agricultural produce that will be included in the list of such objects in the 2016-2018 marketing year are not identified yet. Therefore, it is hoped that Ukraine will determine the volume of purchases of this grain, as well as other crops, and redistribute the funds allocated for such purchases in the country's budget.

Ukraine has everything that is needed to grow its own rice industry. The favorable natural and climatic conditions of southern Ukraine, the availability of engineered rice irrigation systems, the close cooperation and friendship of the Rice Institute with commodity producers, varieties of domestic breeding, environmentally safe cultivation technology make it possible to obtain high yields. Monsoon countries that, due to weather conditions, harvest twice a year do not have much higher rice yields and sometimes even lower than Ukraine does.

The formation of a cereal market, both at the regional level and in the country as a whole, foresees, first of all, the development of horizontal links that rely on market infrastructure, which allows maintaining and regulating market relations in the large economy. In this regard, there is a need to develop new elements of market infrastructure, giving them the necessary legal and economic power.

Creating conditions for the commodity zones of a cereal market will require the use of a set of measures that regulate the process of transition to market relations and at the same time allow to form and develop it with its inherent elements: freedom of enterprise, the right of the manufacturer to dispose of their products and income, competition, elimination of monopoly, pricing depending on supply and demand, etc.

In today's environment, the cereals market is an objective necessity, which allows to improve the country's grain supply through its own production, and to increase its efficiency. However, the orientation of the large-scale economy on market relations, as a means of automatic solution of all its problems, will not be able to radically change the situation in the production, marketing and use of grain in the coming years, since the legislative and regulatory framework is not yet fully formed.

Thus, despite the difficult weather conditions, the grain industry provides sustainable production, which guarantees the food and economic security of the country. Cereals are the basis for the formation and maintenance of the state's strategic food, feed and export balance.

\section{References:}

Averchev, O. V. (2015). Growth, development and productivity of buckwheat depending on the terms and methods of sowing and seed rates. Collection of scientific papers of the Uman State Academy, 53, 61-66.

Orlenko, O. V. (2016). Theoretical-methodological and applied principles of functioning of the grain industry in Ukraine. Extended abstract of dissertation of Doctor of Economical Sciences. 08.00.03. Classic Private University of Zaporizhzhia.

Scorohod, I. S. (2011). Directions for Increasing Ukraine's Competitiveness in World Markets. Lesya Ukrainka Volyn National University, no. 2.

The state of food insecurity in the world. Available at: http://www.fao.org/docrep/i0876e00.htm (accessed 22 May 2019).

The Grit of Truth. Suggestion: The Main Journal of Agribusiness. Available at: http://propozitsiya.com/ua/analizrynku-krup-eksport-vygidnishe-vnutrishnogo-rynku (accessed 24 May 2019).

Informational digest. Available at: https://pro-consulting.ua/ua/pressroom/varim-svoyu-kashu-ob-osnovnyhrezultatah-issledovaniya-rynka-krup-v-ukraine (accessed 26 May 2019). 
Official site of the State Statistics Service of Ukraine. Available at: http://www.ukrstat.gov.ua/ (accessed 26 May 2019 ). Ukrainian market of cereals shows positive dynamics. Suggestion: The Main Journal of Agribusiness. Available at: http://propozitsiya.com/ua/analiz-rynku-krup-eksport-vygidnishe-vnutrishnogo-rynku (accessed 28 May 2019). Analysis of cereals market. Export is more profitable than the domestic market. Proposal: The Main Journal of Agribusiness. Available at: http.//propozitsiya.com/ua/analiz-rynku-krup-eksport-vygidnishe-vnutrishnogo-rynku (accessed 28 June 2019).

Bondarenko, S. M. (2017). An assessment of the quality level of products at an enterprise. An efficient economy, no. 4. Available at: http://www.economy.nayka.com.ua/?op=1\&z=5527 (accessed 10 May 2019).

Organoleptic methods of quality determination. Available at: https://docs. google.com/document/d/1SIZ79fAN crsMC11ZMIjXOVchHtbmQUWE8FxFRUEXZuw/edit (accessed 08 May 2019).

Requirements for the cereals quality. Available at: https://studfiles.net/preview/5118611/page:4/ (accessed 10 May 2019).

Eurostat (2018). The EU in the world - agriculture, forestry and fisheries. Extracted April 2018. Available at: https://ec.europa.eu/eurostat/statistics-explained/index.php/The_EU_in_the_world_-_agriculture,_forestry_ and_fisheries (accessed 10 May 2019).

Hart, K., Allen, B., Keenleyside, C., Nanni, S., Maréchal, A., Paquel, K., Nesbit, M. \& Ziemann, J. (2017). Research for AGRI Committee - The consequences of climate change for EU agriculture. Follow-up to the COP21 - UN Paris Climate Change Conference, Brussels: European Parliament: Agriculture and Rural Development. Available at: http://www.europarl.europa.eu/RegData/etudes/STUD/2017/585914/IPOL_STU(2017)585914_EN.pdf (accessed 10 May 2019).

Harvey, F. (2016). Use of strongest antibiotics rises to record levels on European farms', The Guardian. 